\title{
First report of the Middle Devonian stringocephalid genus Paracrothyris (Brachiopoda) from North Africa
}

\author{
MENA SCHEMM-GREGORY \& ULRICH JANSEN
}

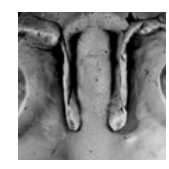

\begin{abstract}
The stringocephalid genus Paracrothyris Wu in Wang et al., 1974 is reported for the first time from Givetian beds of the Western Sahara (Northwest Africa). Although only dorsal shell fragments have been found, the specimens can be assigned to this genus with certainty due to a combination of preserved characters: lack of a median septum, and the presence of crural plates in combination with a typical stringocephaloid morphology. The genus Paracrothyris (type species P. distorta Wu in Wang et al., 1974) was originally described from South China and later from Nevada, U.S.A., and has only been reported from beds of Givetian age (late Middle Devonian). From the palaeogeographical distribution, it is concluded that the larvae migrated throughout the Palaeotethys along the shelf of Northern Gondwana between Nevada and South China, supporting the hypothesis of decreasing provincialism in late Middle Devonian time. - Key words: Paracrothyris, Brachiopoda, Western Sahara, Gondwana, Givetian, Middle Devonian.
\end{abstract}

SCHEMM-GREGORY, M. \& JANSEN, U. 2008. First report of the stringocephalid genus Paracrothyris (Brachiopoda, Middle Devonian) from North Africa. Bulletin of Geosciences 83(2), 169-173 (3 figures, 1 table). Czech Geological Survey, Prague. ISSN 1214-1119. Manuscript received December 5, 2007; accepted in revised form January 24, 2008; issued June 30, 2008.

Mena Schemm-Gregory \& Ulrich Jansen, Forschungsinstitut Senckenberg, Paläozoologie III, Senckenberganlage 25,D-60325 Frankfurt am Main, Germany; Mena.Schemm-Gregory@senckenberg.de (corresponding author), Ulrich.Jansen@senckenberg.de

The study area is close to the small military town of Smara, Western Sahara, Northwest Africa (Fig. 1). The outcrops are still little known from a palaeontological point of view because it has been difficult to get access to this region due to political reasons. The first published geological studies of this area were conducted during the petroleum prospection in the 1960's (e.g., Dumestre \& Illing 1967).

In the present project, several reef complexes along the southern flank of the Tindouf Basin in Western Sahara have been examined. The material studied was found in a large stromatoporoid-bryozoan-coral reef complex, called "Sabkhat Layfarina" in previous works (Königshof et al. 2003, Schemm-Gregory \& Jansen 2005). Paracrothyris is interpreted to have lived attached by its pedicle to the sea floor in reefs or in environments close to the reef itself. Judging from the brachiopod fauna, such as Nalivkinaria issoumourensis (Drot, 1971) and "Kransia parallelepipeda" (Bronn, 1837), the age of this reef complex is assigned to the late Givetian (late Middle Devonian) (Schemm-Gregory \& Jansen 2005).

The studied specimens from the Western Sahara are determined here as Paracrothyris n. sp. A. Open nomenclature is chosen because only dorsal valves have been found. However, the 14 incomplete valves collected show sufficient diagnostic features of the interior (Fig. 2) to allow an assignment to the genus Paracrothyris. The systematics follow Lee (2006) in the recent revision of the Brachiopod Treatise on Invertebrate Paleontology. The reason why there are no ventral shells preserved is still unsure. The shells were postmortally disarticulated and transported, and because of different possible hydrodynamic behaviours of the valves, the two sets were selectively deposited.

This study is part of a German-Moroccan co-operation programme "Genesis of Devonian Reefs" conducted by following institutions: Forschungsinstitut Senckenberg, Frankfurt am Main (Germany), Ministère de l'Energie et des Mines, Rabat (Morocco), Institut Scientifique, Département de Géologie, Rabat-Agdal (Morocco), and Centre Régional de la Géologie de Laayoune (Morocco). The first expedition to the Western Sahara in 2002 was financed by the Paul Ungerer Foundation.

All studied specimens are deposited in the Forschungsinstitut Senckenberg, Frankfurt am Main, Germany. The illustrated specimens were coated with magnesium oxide. Drawings were made with the help of a camera lucida. Measurements were taken using digital calipers and rounded to $0.1 \mathrm{~mm}$.

Institutional abbreviations. - SMF, Forschungsinstitut Senckenberg, Frankfurt am Main, Germany; USNM, Nati- 


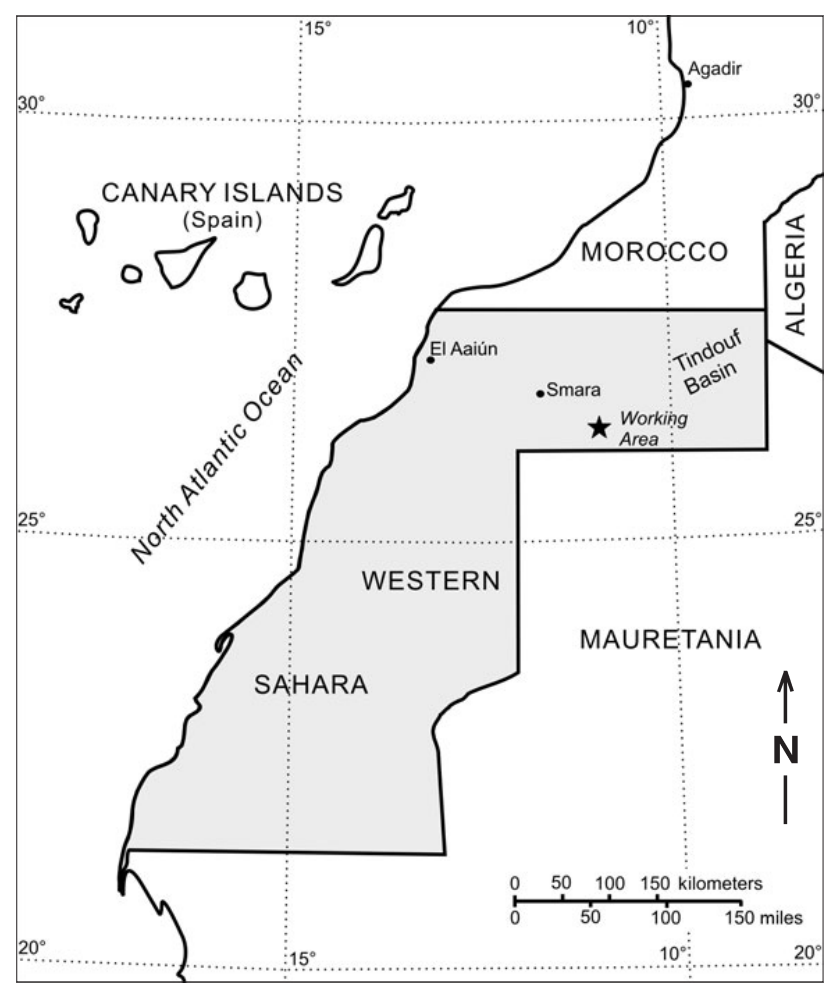

Figure 1. Topographical map of Western Sahara (Northwest Africa) showing the study area.

onal Museum of Natural History, Smithsonian Institution, Washington D.C., U.S.A.

\section{Systematic palaeontology}

Order Terebratulida Waagen, 1883

Suborder Terebratulidina Waagen, 1883

Superfamily Stringocephaloidea King, 1850

Family Stringocephalidae King, 1850

Subfamily Geranocephalinae Johnson, 1975

\section{Genus Paracrothyris Wu in Wang et al., 1974}

Type species. - Paracrothyris distorta Wu in Wang et al., 1974.

Diagnosis. - Shells medium sized, ventri-biconvex. External surface smooth. Dental plates short. Median septum absent in both valves. Crural plates present. Cardinal plate formed by conjunct hinge plates; large, terminally bifid cardinal process. Loop unknown (after Lee 2006).

Geographic and stratigraphic distribution. - South China, Nevada (U.S.A.) and Western Sahara (Northwest Africa); Givetian (upper Middle Devonian).

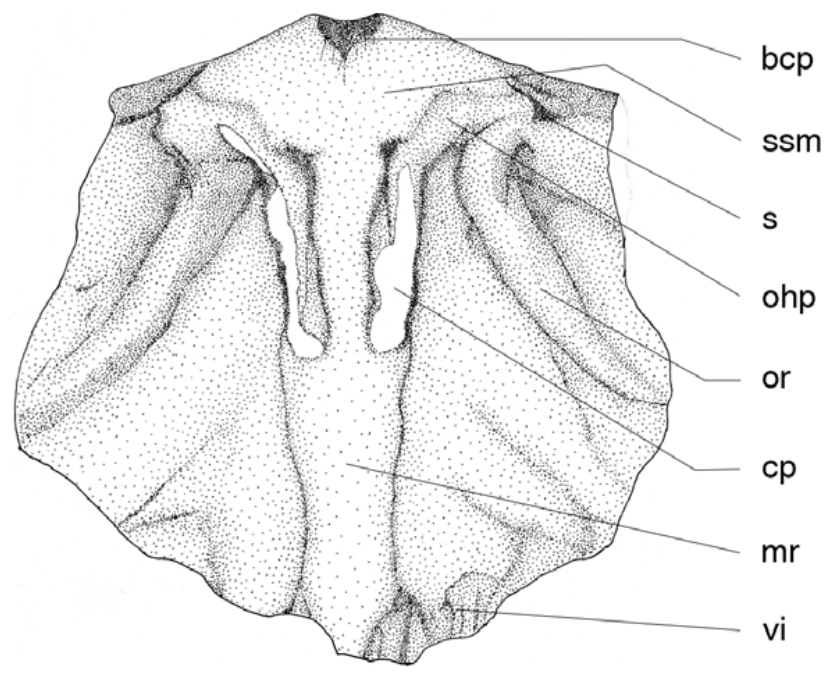

Figure 2. Morphological terminology of the posterior part of the dorsal valve interior (SMF 66087). Abbreviations: bcp - base of cardinal process, ssm - secondary shell material, s - socket, ohp - outer hinge plate, or - oblique ridge, $\mathrm{cp}$ - crural plate (= inner hinge plate), $\mathrm{mr}$ - median ridge, vi - visceral impressions. Drawing: M. Schemm-Gregory.

Paracrothyris n. sp. A

Figures 2, 3A-Q

Material. - SMF 66087, 66297-66309: 14 incompletely preserved dorsal valves. Data on the specimens, including their collecting localities and measurements, are listed in Table 1.

Geographic and stratigraphic distribution. - Near Smara, Western Sahara (Northwest Africa), Sabkhat Layfarina reef complex, Upper Givetian (upper Middle Devonian).

Description. - The external surface of the shell of Paracrothyris n. sp. A is smooth. The preserved parts of the dorsal valve are gently convex to almost flat, the largest incomplete valve is $50.5 \mathrm{~mm}$ wide. The narrow dorsal interarea is hypercline and low. The cardinal process is not completely preserved in the specimens studied and its base is bifid, as specimens SMF 66303, SMF 66306, and SMF 66307 indicate (Fig. 3G, P, Q). The outer hinge plates are discrete and oriented almost parallel to the hinge line pointing in a dorsal direction. The inner hinge (= crural) plates are long, oriented parallel to each other on the outer sides of the median ridge, and point in an anterior direction; they converge basally to enclose the dorsal adductor field. In gerontic stage, they can become very thick, with their anterior margin being fused with the median ridge (Fig. 3A, G). Crura and crural bases are not preserved, and the loop is unknown. The dental sockets are narrow and rounded in cross-section. They are situated postero-lateral to the outer hinge plates, the apices pointing in an apical direction. The posterior parts of the outer hinge plates, the inner 


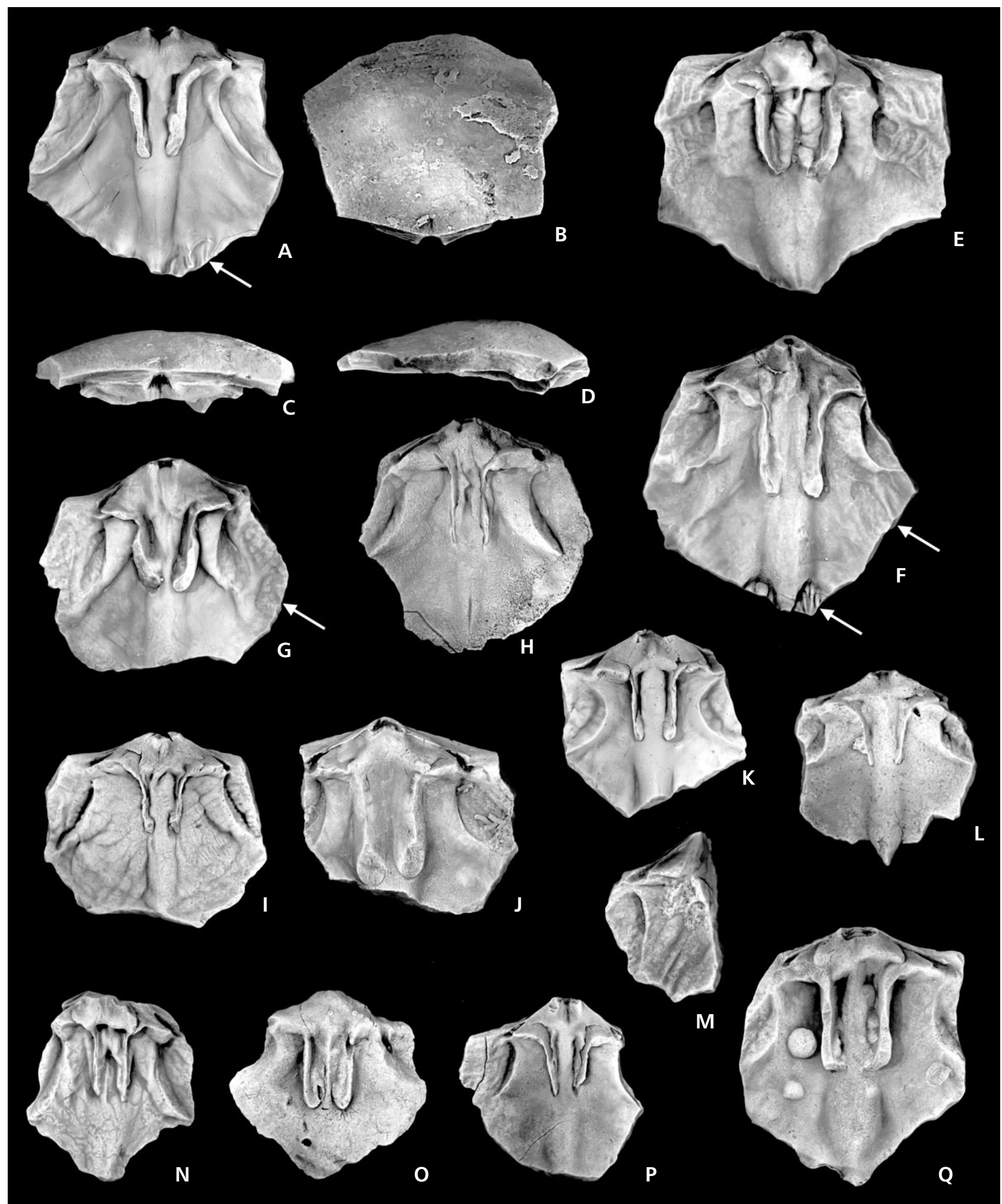

Figure 3. Paracrothyris n. sp. A, Sabkhat Layfarina reef complex, Western Sahara (Northwest Africa); Middle Devonian, Upper Givetian. All figures are in original size $(\times 1.0)$ and unless otherwise noted show plan view of internal surface of dorsal valve. $\bullet A-D-S M F 66087$. Plan view of dorsal interior, oblique posterior, posterior, and lateral views of dorsal exterior. Arrow pointing to visceral impressions. $\bullet$ E - SMF 66304 . $\bullet$ F - SMF 66298 . Upper arrow pointing to impressions of mantle canal system, lower arrow pointing to visceral impressions. $\bullet \mathrm{G}-\mathrm{SMF} 66307$. Arrow pointing to impressions of

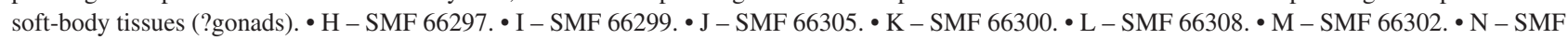
66301. $\bullet$ O - SMF 66309. • P - SMF 66306. Q Q - SMF 66303. 
Table 1. List of the material of Paracrothyris n. sp. A including width of the fragments and collecting locality.

\begin{tabular}{|c|c|c|}
\hline $\begin{array}{l}\text { Inventory } \\
\text { number }\end{array}$ & Collecting locality & $\begin{array}{l}\text { Width of } \\
\text { fragment }\end{array}$ \\
\hline SMF 66087 & $\mathrm{~N} 26^{\circ} 31^{\prime} 425^{\prime \prime}, \mathrm{W} 11^{\circ} 31^{\prime} 863^{\prime \prime}$ & $43.25 \mathrm{~mm}$ \\
\hline SMF 66297 & $\mathrm{~N} 26^{\circ} 33^{\prime} 356^{\prime \prime}, \mathrm{W} 11^{\circ} 29^{\prime} 539^{\prime \prime}$ & $43.05 \mathrm{~mm}$ \\
\hline SMF 66298 & $\mathrm{~N} 26^{\circ} 31^{\prime} 425^{\prime \prime}, \mathrm{W} 11^{\circ} 31^{\prime} 863^{\prime \prime}$ & $38.79 \mathrm{~mm}$ \\
\hline SMF 66299 & $\mathrm{~N} 26^{\circ} 31^{\prime} 425^{\prime \prime}, \mathrm{W} 11^{\circ} 31^{\prime} 863^{\prime \prime}$ & $37.81 \mathrm{~mm}$ \\
\hline SMF 66300 & $\mathrm{~N} 26^{\circ} 31^{\prime} 425^{\prime \prime}, \mathrm{W} 11^{\circ} 31^{\prime} 863^{\prime \prime}$ & $31.54 \mathrm{~mm}$ \\
\hline SMF 66301 & $\mathrm{~N} 26^{\circ} 31^{\prime} 425^{\prime \prime}, \mathrm{W} 11^{\circ} 31^{\prime} 863^{\prime \prime}$ & $28.83 \mathrm{~mm}$ \\
\hline SMF 66302 & $\mathrm{~N} 26^{\circ} 31^{\prime} 425^{\prime \prime}, \mathrm{W} 11^{\circ} 31^{\prime} 863^{\prime \prime}$ & $20.44 \mathrm{~mm}$ \\
\hline SMF 66303 & $\mathrm{~N} 26^{\circ} 33^{\prime} 356^{\prime \prime}, \mathrm{W} 11^{\circ} 29^{\prime} 539^{\prime \prime}$ & $47.23 \mathrm{~mm}$ \\
\hline SMF 66304 & $\mathrm{~N} 26^{\circ} 33^{\prime} 356^{\prime \prime}, \mathrm{W} 11^{\circ} 29^{\prime} 539^{\prime \prime}$ & $50.51 \mathrm{~mm}$ \\
\hline SMF 66305 & $\mathrm{~N} 26^{\circ} 33^{\prime} 356^{\prime \prime}, \mathrm{W} 11^{\circ} 29^{\prime} 539^{\prime \prime}$ & $37.18 \mathrm{~mm}$ \\
\hline SMF 66306 & $\mathrm{~N} 26^{\circ} 33^{\prime} 356^{\prime \prime}, \mathrm{W} 11^{\circ} 29^{\prime} 539^{\prime \prime}$ & $31.54 \mathrm{~mm}$ \\
\hline SMF 66307 & $\mathrm{~N} 26^{\circ} 33^{\prime} 356^{\prime \prime}, \mathrm{W} 11^{\circ} 29^{\prime} 539^{\prime \prime}$ & $42.50 \mathrm{~mm}$ \\
\hline SMF 66308 & $\mathrm{~N} 26^{\circ} 33^{\prime} 356^{\prime \prime}, \mathrm{W} 11^{\circ} 29^{\prime} 539^{\prime \prime}$ & $31.11 \mathrm{~mm}$ \\
\hline SMF 66309 & $\mathrm{~N} 26^{\circ} 33^{\prime} 356^{\prime \prime}, \mathrm{W} 11^{\circ} 29^{\prime} 539^{\prime \prime}$ & $33.85 \mathrm{~mm}$ \\
\hline
\end{tabular}

hinge plates, and the inner socket ridges are deeply embedded in thick secondary shell material. There is a thick and low median ridge starting from the apical region of the dorsal valve. This ridge reaches a width of about $5 \mathrm{~mm}$ and is rounded in cross section; its top can be flattened. The anterior end of the median ridge is not preserved in any specimen. Anterior to the outer hinge plate begins a pair of oblique ridges running in an antero-lateral direction and convexly curved towards the median ridge. This structure is interpreted as providing strengthening to the dorsal valve to prevent it from breaking. The thickness of the posterior part of the dorsal shell increases during the ontogeny. Irregular impressions of the mantle canal system originate between the crural plates and the oblique ridges (Fig. 3F). Further impressions of soft body organs (?gonads) are discernable postero-lateral to the oblique ridges (Fig. 3G). Anterior to the crural plates, two specimens (Fig. 3A, F) show the posterior part of other visceral impressions. No other anterior parts are preserved in any specimen.

Discussion. - The absence of a median septum, the presence of crural plates and the thickness of the shell, in combination with other stringocephalid features, has led to the determination as Paracrothyris n. sp. A. Unfortunately, it was possible to compare our material side-by-side only with Paracrothyris sp. from Nevada (USNM 140452), specimens figured in Boucot et al. (1966, pl. 170, figs 8, 9) and Johnson (1975, text-fig. 1A, B). The type material of Wu in Wang et al. (1974), as well as other specimens of Paracrothyris distorta from South China, stored at the Nanjing In- stitute for Geology and Palaeontology, Academia Sinica, were also not accessible during our visits, so we referred only to the literature. Yang et al. (1977, pp. 462-464, pl. 185 , fig. 4; pl. 186, fig. 4; pl. 187, figs 6, 8-10) erected four new species of Paracrothyris, all distinguished by variations of external form and size and all smaller than our material. The specimens of the type species illustrated by Wu (in Wang et al., 1974, pl. 15, figs 8-13) show large and ventri-biconvex to almost equi-biconvex articulated specimens with a gentle curvature of both valves. The cross section shows crural plates and a median ridge that is more highly elevated than in Paracrothyris n. sp. A from Western Sahara. The specimens of Paracrothyris sp. from Nevada on the other hand are very small and are regarded here as juvenile specimens; the largest is $12.1 \mathrm{~mm}$ wide. As in the Western Saharan material, only the posterior parts of the dorsal valves are preserved. The crural plates are very short and the median ridge delicate and hardly thickened. The oblique ridges that are clearly developed in Paracrothyris n. sp. A from Western Sahara are not seen in Paracrothyris sp. from Nevada. Probably they appeared later in the ontogeny of this species. The ridges are also not visible in the illustrated material of Paracrothyris distorta from South China, but this might only be due to the position of the cross section. Paracrothyris sp. from Nevada shows a gap between the median ridge and the cardinal process. This part of the cardinalia is completely embedded in secondary shell material in the specimens from the Western Sahara. It remains speculative if there was a gap in an earlier ontogenetic stage similar to the one in Paracrothyris sp. from Nevada. The material studied indicates that the shells of Paracrothyris were originally large, even larger than the type species. Some of the incomplete specimens from the Western Sahara have already the same width as the holotype, which is a completely preserved specimen.

From the presence of Paracrothyris in South China, Nevada, and North Africa, it is assumed that a faunal exchange between the three regions was possible during late Givetian time. Larvae of Paracrothyris could have migrated along the North Gondwanan shelf within the Palaeotethyan seaway (between Nevada and South China). Accordingly, the migration barrier assumed by Boucot \& Blodgett (2001) to have separated North America from Gondwana and Europe during the Early Devonian is here interpreted to have disappeared before the late Givetian.

\section{Acknowledgements}

This is a contribution to UNESCO: IUGS IGCP Project 499 " $D e$ vonian land-sea interaction: evolution of ecosystems and climate - DEVEC'. M.S.-G. is very grateful to Jann Thompson (Smithsonian Institution, National Museum of Natural History, Washington D.C., U.S.A.) for giving access to the brachiopod 
collection. U.J. thanks his Moroccan colleagues Ahmed El Hassani (Institut Scientifique Départment de Géologie, RabatAgdal), Mohammed Bensaïd (Ministère de l'Energie et des Mines, Rabat), and Ech-Charki Rjibati (Centre Régional de la Géologie de Laayoune, Laayoune) for excellent guidance in the field and for the very good organisation of the expedition. We are grateful to Paul Sartenaer (Institut royal des Sciences naturelles de Belgique, Brussels) for the determination of the rhynchonellid brachiopods and discussion of the stratigraphic assignment of the study area. Both authors acknowledge Alexander J. Bartholomew (State University of New York, New Paltz) and Art J. Boucot (Oregon State University, Corvallis, both U.S.A.) for improving the English of an earlier draft. The manuscript also benefited from the reviews by Fernando Alvarez (Universidad de Oviedo, Spain), Andrzej Baliński (Instytut Paleobiologii PAN, Warszawa, Poland), and Robert Blodgett (U.S. Geological Survey, Anchorage, U.S.A.).

\section{References}

Boucot, A.J. \& Blodgett, R.B. 2001. Chapter 34 - Silurian-Devonian biogeography, 335-344. In BRUNTON, C.H.C., Cocks, L.R.M. \& LONG, S.L. (eds) Brachiopods Past and Present. The Systematics Association Special Volume Series 63. Taylor \& Francis, London \& New York.

Boucot, A.J., Johnson, J.G. \& STRUVE, W. 1966. Stringocephalus, ontogeny and distribution. Journal of Paleontology 40, 1349-1364.

BRONN, H.G. 1837. Lethaea geognostica oder Abbildungen und Beschreibungen der für die Gebirgs-Formationen bezeichnendsten Versteinerungen. Vol. 1, 481-768. Schweizerbart, Stuttgart.

DROT, J. 1971. Rhynchonellida siluriens et dévoniens du Maroc présaharien. Nouvelles observations. Notes du Service géologique du Maroc 237, 65-108.
Dumestre, A. \& Illing, L.V. 1967. Middle Devonian reefs in Spanish Sahara, 333-350. In OswALD, D.H. (ed.) International Symposium on the Devonian System, Vol. 2. Alberta Society of Petroleum Geologists, Calgary.

JOHNSON, J.G. 1975. Asian stringocephaloid brachiopod genera Omolonia and Paracrothyris in the Middle Devonian of Western North America. Journal of Paleontology 49, 979-983.

KING, W. 1850. A monograph of the Permian fossils of England. Palaeontographical Society Monograph 3(1), 1-258.

Königshof, P., Wehrmann, A., SChIndLER, E., JANSEN, U. \& PlODOWSKI, G. 2003. Geologische Expedition in die westliche Sahara. Natur und Museum 133, 302-310.

Lee, D.E. 2006. Stringocephaloidea, 1994-2018. In Kaesler, R.L. (ed.) Treatise on Invertebrate Paleontology. Part H. Brachiopoda (Revised). Vol. 5: Rhynchonelliformea (part). Geological Society of America \& University of Kansas Press, Boulder \& Lawrence.

SCHEMM-GREGORY, M. \& JANSEN, U. 2005. Middle and Upper Devonian Brachiopods from the Western Sahara (Morocco), 27. In HARPER, D.A.T., LONG, S.L. \& MCCORRY, M. (eds) Abstracts Fifth International Brachiopod Congress. Natural History Museum of Denmark, University of Copenhagen, Copenhagen.

WaAgen, W.H. 1883. Salt Range Fossils. I. Productus-Limestone Fossils. Geological Survey of India, Memoirs, Palaeontologia Indica (series 13) 4(2), 391-546.

WANG YU, YU CHANG-MIN \& WU QI 1974. Advances in the Devonian biostratigraphy of South China. Memoirs of Nanjing Institute of Geology and Palaeontology, Academia Sinica 6, 1-71 [in Chinese].

YANG DE-LI, Ni SHI-ZHAO, CHANG MEI-LI \& ZHAO RU-XUAN 1977. Brachiopoda, 306-470. In YANG DE-LI, NI SHI-ZHAO, CHANG MEI-Li \& ZHAO RU-XUAN Palaeontological Atlas of Central-South China (Late Paleozoic Part), Vol. 2. Geological Publishing House, Beijing. 